\title{
Towards male sterility in Cryptomeria japonica using the male strobilus-specific genes of C. japonica
}

\author{
Kurita Manabu ${ }^{1 *}$, Watanabe Atsushi ${ }^{2}$, Konagaya Ken-ichi ${ }^{1}$, Tsubomura Miyoko ${ }^{2}$, Hirao Tomonori ${ }^{1}$, Ishii Katsuaki ${ }^{1}$, \\ Taniguchi Toru'
}

From IUFRO Tree Biotechnology Conference 2011: From Genomes to Integration and Delivery Arraial d'Ajuda, Bahia, Brazil. 26 June - 2 July 2011

\section{Background}

Cryptomeria japonica D. Don (sugi) is one of the most important Japanese conifer species. Rapid improvement of the wood trait (e.g., growth speed and wood quality) using a conventional breeding approach is not possible, because breeding of coniferous tree requires a very long time. Genetic modification might be a powerful tool to shorten the time needed to breed trees compared with traditional breeding methods because it is able to induce the favorable traits by introduction of specific genes in trees without unnecessary genetic transitions. But the transfer of foreign genes from GM plants to related plant species by pollen has been cited as an environmental concern. For the purpose of creating male sterile GM C. japonica, we attempted to identify genes related to male flower formation.

\section{Methods}

To isolate the male strobilus specific genes, we constructed male strobilus specific SSH libraries based on three different stages according to male strobilus development; early stage, tetrad stage and mature stage. The microarray were designed using 19,259 genes consisting of isolated genes from SSH libraries and ForestGen (FORest EST and GENome database [http://forestgen. ffpri.affrc.go.jp/en/index.html]).We analyzed expression profiling associated with male strobilus development. To isolate the male strobilus specific promoter of male strobilus specific genes, 1009-C47 and 1009-C96, TAIL-PCR methods were performed. To confirm the tissue specific

\footnotetext{
* Correspondence: mkuri@affrc.go.jp

'Forest Bio-Research Center, Forestry and Forest Products Research Institute, Japan

Full list of author information is available at the end of the article
}

activity of the promoter regions, the promoter::GUS fusions were introduced into Arabidopsis and C. japonica. Furthermore, we introduced 1009-C47::Barnase and 1009-C96::Barnase to Arabidopsis and C. japonica. We evaluated the ability of pollen formation of the transgenic Arabidopsis that introduced 1009-C47::Barnase and 1009-C96::Barnase construct.

\section{Results and discussion}

The microarray analysis was performed using cDNA of different developmental stages of male strobilus; early stage, microspore mother cell stage, tetrad stage, free spore stage and mature pollen stage. We showed that the strongly expressed genes in each developmental stage were markedly different. The GUS assay revealed that the 1009-C47::GUS showed anther-specific GUS activity in Arabidopsis and C. japonica. The introduction of 1009-C47::Barnase and 1009-C96::Barnase into Arabidopsis led to male sterility phenotype. We showed probability that the 1009-C47 promoter and 1009-C96 promoter are useful for male sterilization of $C$. japonica.

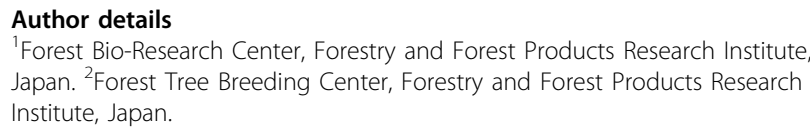

${ }^{1}$ Forest Bio-Research Center, Forestry and Forest Products Research Institute, Japan. ${ }^{2}$ Forest Tree Breeding Center, Forestry and Forest Products Research Institute, Japan.

Published: 13 September 2011

doi:10.1186/1753-6561-5-S7-P180

Cite this article as: Manabu et al:: Towards male sterility in Cryptomeria japonica using the male strobilus-specific genes of $C$. japonica. BMC

Proceedings 2011 5(Suppl 7):P180.

\section{() Biomed Central}

(C) 2011 Manabu et al; licensee BioMed Central Ltd. This is an open access article distributed under the terms of the Creative Commons Attribution License (http://creativecommons.org/licenses/by/2.0), which permits unrestricted use, distribution, and reproduction in any medium, provided the original work is properly cited. 